\title{
RECENT EXTENSIONS OF MUNICIPAL FUNCTIONS IN THE UNITED STATES
}

\author{
By Professor John A. Fairlie, \\ Of the University of Michigan.
}

During the past few years there has been much agitation in the United States in favor of the extension of municipal functions. This has had particular reference to undertakings which have hitherto been operated by private corporations acting under special franchises for the use of the public streets. There has been a corresponding amount of discussion in opposition to such proposals, which has been strengthened by the criticism in Great Britain of what in that country has been called municipal trading. It is not the purpose of this article to consider the arguments on either side of this prolonged debate; but it is intended simply to present a brief record of the recent developments in relation to municipal activities in our own country.

It is no easy matter to bring together even the most important facts for such an account. Neither the national government, nor any one of the states has any official record of what the cities are doing; while the legislation on the subject has been mainly enacted with reference to particular cities. Within the period to be covered, however, there have been a few municipal laws of a general nature, which stand out in marked contrast to the prevailing system of special legislation. The most important of these is the municipal code of Ohio, enacted in 1902 , to correct a situation brought about by decisions of the Supreme Court of that state. These decisions had declared unconstitutional a great mass of legislation passed during the preceding fifty years, to circumvent the constitutional requirement of general uniform legislation. This new code gives to every municipality in the state the same authority, and thus has extended to all every power previously exercised by any one. In 1903 the Virginia assembly passed a law re-enacting and amend[299] 
ing the statutes in reference to cities and towns, to meet the conditions of the new state constitution; and in the same year a New Jersey act was passed for the government of all cities which adopt it. The general tendency of these and other measures is in the direction of increasing the functions of municipalities in the United States, especially in the field of municipal ownership and operation of what are vaguely called public services, but at the same time to do so by continuing the policy of specific enumerated grants of power. There is no evidence of any change to the policy of the countries of continental Europe, where cities have general authority to undertake any functions affecting the interests of the city, subject only to the specific restrictions and regulations imposed by the central administration. Along with this increase in the active operations of cities, may be noted a tendency to restrict the discretion of city councils in granting franchises conferring special privileges in the public streets.

\section{Public Safety.}

Turning to an examination of more specific functions, we may note first the situation in the field of public safety, or the measures for protecting life, liberty and property. Here the most striking changes have been, not in the direction of extending municipal activities, but in the assumption by the states of functions formerly left to local communities. This has been done in two ways: by the establishment of small bodies of state police, for service anywhere in the state; and by giving the management of municipal police to state appointed boards. Apparently the first action in reference to a distinctively state police was taken by Massachusetts in 1865 , when a small force of state constables was established mainly for the enforceof the law prohibiting the liquor traffic. On the repeal of the prohibition law in 1875 the state police was continued as a detective force to aid in the suppression of disorder and the enforcement of criminal laws, and its functions have since been extended to include the inspection of factories. More recently the office of fire marshal, for the investigation of fires, has been incorporated with the state police. ${ }^{1}$ Rhode Island in I 886 established a chief of state police with powers of direction over the sheriffs and local police, in connection

\footnotetext{
1 R. H. Whitten, Public Administration in Massachusetts, chap. 6. (Columbia University Studies, Vol. VIII.)
} 
with the enforcemient of the prohibition law then re-enacted in that state. $^{2}$ But this office lasted only a few years. Another brief experiment with state police was made by New Jersey from I89I to 1894 . Soon after the establishment of the system of state liquor dispensaries, South Carolina (in I896) established a force of state constables to aid in the enforcement of liquor laws. ${ }^{3}$ A statute of 1903 further regulates the organization of this force. The governor appoints the chief state constable, who receives a salary of $\$ 1,500$ a year, and this officer appoints seven assistant chief constables and other state constables to assist him in his work. Connecticut has also organized a body of state police (in 1903) similar to that in Massachusetts, specially for the enforcement of the laws relating to intoxicating liquors and gaming, and taking over the functions of the state fire marshal. There is provided a superintendent of police at $\$ 3,000$ a year, an assistant superintendent and from five to ten police officers, all selected by a board of five unpaid commissioners, who in turn are to be chosen biennially by the judges of the superior court.

Of a somewhat different nature are the bodies of mounted rangers established in less settled regions for the suppression of violent disorder and the protection of the Mexican frontier. The Texas rangers, organized in I9OI, may consist of four companies, each composed of twenty-two men, the captains and the quartermaster in command of the whole force being appointed by the governor of the state. In Arizona the rangers as reorganized in 1903 consist of twenty-six men mustered into service by the governor of the territory. Both in Texas and Arizona the governors strongly commend the work of these rangers.

State appointed police boards for particular cities have been established for some time in a considerable number of cities. New York had such a board from 1857 to 1870 ; and during that period similar boards were established for large cities in other states. Then came a period when most of the state boards were abolished. But since 1885 there has been a revival of this system; and it is in existence in St. Louis, Boston, Baltimore, San Francisco, Kansas City, Mo., Fall River, St. Joseph, Birmingham, Manchester, N. H.,

2C. M. L. Sites, Centralized Administration of Liquor Laws, p. 72. (Columbia University Studies, Vol. X.)

Ibid., pp. 73, I18. 
and eleven Indiana cities." Still more recently state police boards have been provided for Newport and Providence, R. I.; while the new Ohio code contains a provision under which boards of public safety have been appointed by the governor of the state in Toledo and eight other cities." The governor appoints these boards in Ohio cities when the mayor's nominations are not confirmed by two-thirds of the council. In Indiana, however, a statute of rgor to place the police and fire departments of Fort Wayne, Terre Haute and South Bend under state boards of public safety has been declared unconstitutional. The police of Cincinnati and Denver have within the past two years been transferred from the control of state boards to locally appointed authorities.

Probably the most important development of municipal activity in the field of public safety has been the work of the new tenement house department in the city of New York established in 1902. This department took over the powers over tenement houses formerly exercised by the departments of health, fire and police, and has important additional powers under the statutes providing for the new department. It conducts an elaborate system of inspections of old buildings, and requires repairs and improvements so as to render them sanitary, safe and habitable. It also supervises the construction of new buildings, and makes systematic inspections to see that there are no violations of the provisions of the law to secure stability of structure, protection from fire, and adequate sanitary conditions. But the requirements of the law still permit a much greater degree of compact building in New York than in the largest cities of Europe. In Germany, dwelling houses even in the business sections must have at least one-third of the area of building lots left as court yards, and in residence sections at least a half. In New York only one-fourth of the lot area must be left unbuilt.

\section{Public Works.}

Steady advance is being made by American cities in providing street paving, street cleaning, garbage disposal, sewer systems, parks and similar public improvements. This development, however, is rather the extension of established fields of municipal action than the

- Terre Haute, South Bend, Anderson, Elkhart, Richmond, Huntington, Jeffersonville, I. Fayette, Logansport, Muncie and New Albany.

- Hamilton, Findlay, Fostoria, Lorain, Middletown, Painesville, Van Wert and Warren.

- C. Hugo: Deutsche Stadtverwaltung, 429, 430. 
inauguration of a new policy. But it is significant of the niggardly methods in legislative grants of municipal powers that even for these functions, clearly accepted as within the proper scope of municipal work, a great deal of additional legislation must be passed every year in order to authorize the necessary undertakings. In regard to street paving, a novel feature has been the establishment of a municipal asphalt plant in the city of Detroit, which repairs and resurfaces asphalt pavements instead of making contracts for this class of work. Some street cleaning is now done in most American cities; and with comparatively few exceptions by a force of municipal employees. The latest returns on this subject are shown in the table below:?

\begin{tabular}{r|r|r|r|r|r}
\hline Grovps of Crirss. & $\begin{array}{r}\text { Number of } \\
\text { Places. }\end{array}$ & $\begin{array}{c}\text { Number } \\
\text { Reporting } \\
\text { Street } \\
\text { Cleaning. }\end{array}$ & $\begin{array}{c}\text { Municipal } \\
\text { Employees. }\end{array}$ & Contract. & Both. \\
\hline Over 30,000 pop'n & 135 & 132 & 115 & 9 & 7 \\
$10,000-30,000 \ldots . .$. & 304 & 291 & 272 & 13 & 4 \\
$5,000-10,000 \ldots . .$. & 465 & 435 & 386 & 30 & 9 \\
$3,000-5,000 \ldots . .$. & 620 & 16 & 466 & 31 & 5 \\
\hline & 1,524 & 874 & 1,239 & 83 & 25 \\
\hline
\end{tabular}

Baltimore and New Orleans, the two largest cities which have had no system of underground sewers, have at last taken up this important work. Many smaller cities are doing the same; and the general situation in regard to sewage is indicated in the following table :

\begin{tabular}{|c|c|c|c|c|}
\hline Groups of Citres. & $\begin{array}{l}\text { Number of } \\
\text { Places. }\end{array}$ & $\begin{array}{l}\text { Number } \\
\text { with } \\
\text { Sewers. }\end{array}$ & $\begin{array}{l}\text { Public } \\
\text { Works. }\end{array}$ & $\begin{array}{c}\text { Private } \\
\text { Companies. }\end{array}$ \\
\hline \multirow{5}{*}{$\begin{array}{l}\text { Over } 30,000 \ldots \ldots \ldots \ldots \\
10,000-30,000 \ldots \ldots \ldots \\
5,000-10,000 \ldots \ldots \\
3,000-5,000 \ldots \ldots\end{array}$} & I 35 & I3I & $x$ & . \\
\hline & 303 & 277 & 269 & 8 \\
\hline & $46_{3}$ & 364 & 346 & 15 \\
\hline & 623 & 324 & 299 & I9 \\
\hline & 1,524 & 1,096 & $I, 045$ & 42 \\
\hline
\end{tabular}

IErgineering News, Vol. XLVIII, p. 422.

- unicipal Year Book, rgoa. 
Two undertakings of special importance for the final disposal of sewage should also be noted. In 1900 the Chicago drainage canal was opened, much to the improvement of the Chicago river; and since then there has been a steady progress in the work of connecting other parts of the sewer network in the drainage district with the canal. In Ig02 a state commission was established in New Jersey to construct trunk outfall sewers to carry the drainage from the cities of the densely populated Passaic valley, and a year later the issue of $\$ 9,000,000$ in fifty-year bonds was authorized for this work.

Other works for the improvement of sanitary conditions are water purification plants. The most important new works of this kind are those under way in Philadelphia and Pittsburg.

\section{Municipal Ownership.}

Attempts to extend municipal activity into the disputed field of "public utilities" meet with varying degrees of success with respect to different classes of undertakings. Some additions have been made to the list of municipal water works, Memphis in particular, where public management has already been established. Plans to take over the private works in Denver are apparently defeated for a time. Municipal electric lighting plants are increasing rapidly in number and importance, and the indications are that such undertakings will before many years be as commonly municipal as are the water works at present. The latest attempt in this direction is in the city of New York, and the successful establishment of a municipal plant there would greatly strengthen the movement in this direction throughout the country. Municipal street railways are still only in the stage of discussion and agitation.

Recent investigations make possible a definite record of the present status of municipal undertakings of these kinds. In reference to water works, the following table shows the situation in $1902 .{ }^{\circ}$

A more exhaustive investigation, including the smaller towns, made in 1898 by the United States Department of Labor showed a total of 1,787 municipal water works and 1,539 under private control. It should be noted, however, that the higher proportion of municipal works among the large cities increases the significance of municipal works as a whole. In 1898 the total investment in

- Municipal Year Book, 1902, pp. xxix, xxxi. 


\begin{tabular}{|c|c|c|c|}
\hline Groups of Citirs. & $\begin{array}{l}\text { Total Number } \\
\text { of Water- } \\
\text { works. }\end{array}$ & $\begin{array}{c}\text { Number of } \\
\text { Municipal } \\
\text { Works. }\end{array}$ & $\begin{array}{l}\text { Per cent } \\
\text { Municipal. }\end{array}$ \\
\hline Over 30,000 population. . ........ & 135 & 95 & 70.4 \\
\hline I0,000-30,000 population. . . . . . . & 302 & 152 & 50 \\
\hline $5,000-10,000$ population. . & $45^{8}$ & 234 & 50.1 \\
\hline $3,000-5,000$ population....... & $5^{80}$ & 318 & $50 \cdot 5$ \\
\hline New England States ... & 226 & 143 & $63 \cdot 2$ \\
\hline Middle States . . . . . . . & 335 & I 40 & $4 I \cdot 7$ \\
\hline North Central States....... & 372 & 243 & $65 \cdot 3$ \\
\hline Northwestern States . . . . . . & 150 & 86 & $57 \cdot 3$ \\
\hline South Atlantic States ...... & rof & 64 & 59.8 \\
\hline South Central States ...... & $9 \mathrm{I}$ & $3^{6}$ & $39 \cdot 5$ \\
\hline Southwestern States ...... & 124 & 55 & $43 \cdot 5$ \\
\hline Pacific States ........ & 70 & $3^{2}$ & $45 \cdot 7$ \\
\hline United States & $\mathrm{I}, 475$ & 799 & 54.2 \\
\hline
\end{tabular}

municipal plants was nearly double that in private works. ${ }^{10}$ From the census report on central electric light and power stations, the following data has been compiled showing the number and distribution of municipal plants in $1902::^{11}$

\begin{tabular}{|c|c|c|c|}
\hline Groups of Cities. & $\begin{array}{l}\text { Total Number } \\
\text { Electric Stations. }\end{array}$ & $\begin{array}{l}\text { Number } \\
\text { Municipal. }\end{array}$ & $\begin{array}{l}\text { Per cent. } \\
\text { Municipal. }\end{array}$ \\
\hline 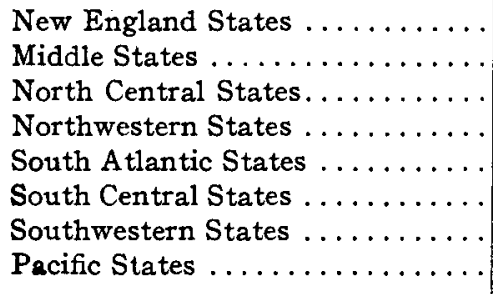 & $\begin{array}{r}3 \times 4 \\
641 \\
1,112 \\
5 \times 1 \\
209 \\
205 \\
381 \\
251\end{array}$ & $\begin{array}{r}35 \\
79 \\
341 \\
145 \\
64 \\
64 \\
62 \\
25\end{array}$ & $\begin{array}{l}11.1 \\
12 \cdot 3 \\
30 \cdot 7 \\
28 \cdot 4 \\
30.6 \\
31.2 \\
16.3 \\
10\end{array}$ \\
\hline United States . . . . . . . . & 3,624 & 815 & $.22 \cdot 5$ \\
\hline
\end{tabular}

As municipal electric light works are found mostly in small cities, these figures exaggerate the importance of municipal lighting. Measured by horse power and output in kilowatts the municipal

10 Report of the Commissioner of Labor, 1899 , p. 12.

a Census Bulletin, Nov. 5, 1903. 
plants furnish about 8 per cent. or 9 per cent. of the electric lighting and about 20 per cent. of the public street lighting. In the states where municipal plants are most frequent the proportion is naturally much higher, the maximum for any state being found in Michigan, where municipal plants furnish about 30 per cent. of the total electric lighting and nearly two-thirds of the public street lighting.

Municipal gas works are still very infrequent in the United. States. In 1902 there were only twenty, as compared with $96 \mathbf{I}$ cities with private gas works; while the municipal works are in small cities, and their total output is less than one per cent. of the illuminating gas produced. ${ }^{12}$

While there is now no street railway operated by a municipal government in this country, Boston and New York have taken long steps in the direction of municipal ownership of underground roads, leasing them for a term of years to operating companies. To the original Boston subway, completed some years ago, there has been added a tunnel under the harbor to East Boston; and work has been begun on a new subway under Washington street. A much larger undertaking has been the New York subway. The first lines contracted for, sixteen miles in length and costing $\$ 35,000,000$, were opened to service in October, 1904; construction is actively proceeding on a second line under the East River to Brooklyn, and additional lines are being proposed.

In addition to the special legislation authorizing particular municipal undertakings of this kind for individual cities, there has been enacted within the past few years a number of statutes conferring broader and more general authority on cities. The new Ohio municipal code authorizes municipal water works and electric lighting plants in every city in that state; and the law governing bond issues confers financial powers sufficient to make the other grant effective. A Missouri act of I903, applying to cities of less than 30,000 population, is the broadest in the scope of powers conferred. This authorizes such municipalities to undertake any public utility, and specifies not only water works and light, heat and power plants, but also telephones and street railways. Such undertakings will be under the control of a board of public works consisting of four members appointed by the mayor and council, not more than two of the same political party. This act is, however, not likely to extend

\footnotetext{
Census Bulletin, No. 123.
} 
very largely the scope of municipal action, as there is no provision for financing these undertakings either by the issue of bonds or in any other way. A Kansas act of the same year authorizes in cities under 15,000 population, municipal water works, and gas, oil and electric plants, to secure which bonds may be issued on a vote of the electors, up to the general debt limit of 15 per cent. of the assessed value of the property. The general municipal act for larger Kansas cities only provides for municipal water and lighting plants at some time in the future, but Atchison and Leavenworth have received special authority to establish municipal water works.

A California act of 1903 , amending the powers of cities under 3,000 population, adds authority to establish and manage water works, wharves, street railways, telephone and telegraph lines, and lighting and heating plants; but like the Missouri act this fails to give adequate financial powers. Under the new general municipal law in Virginia, cities are authorized to provide water works; and bonds issued with the approval of the voters for this or other revenue-producing undertakings are not included within the debt limit so long as the revenue is sufficient to pay the cost of maintenance, interest on bonds and insurance, and to provide a sinking fund.

Perhaps the most significant statute of recent years providing for an extension of municipal administration in this direction is an Illinois law of 1903, atthorizing the cities in that state to own and operate street railways. Not that this act is likely to be followed at once by the establishment of a number of municipal railways, for the act was intended primarily only for the city of Chicago, and even this city, the friends of the measure explained, did not propose to establish a municipal road in the near future, but wished the authority in order to strengthen the hands of the municipal authorities in negotiating for extensions and renewals of franchises to private companies. Nevertheless the act is of special significance because, in addition to the formal grant of authority, there is a careful attempt to provide a satisfactory method of meeting the serious financial difficulties involved in this new departure, so that the grant of power will be effective and adequate whenever it is considered advisable to make use of the authority.

This act applies to all cities in the State of Illinors, but before any of the powers conferred can be exercised the act must first be adopted as a whole by popular referendum in the city concerned, 
while additional referendum votes must be taken in reference to various special features of the law. The authority given is "to construct, acquire, purchase, maintain and operate street railways within the corporate limits," and franchises granted before this power is acted on, may contain a reservation of the right on the part of the city to take over the plant at some future time. Two methods are provided for securing funds for purchasing or constructing municipal railways. General city bonds may be issued, provided the proposition is submitted to popular vote and approved by two-thirds of those voting, but the debt limit is almost certain to prevent this method from being adopted. The other alternative-and this is the most striking feature of the act-is to issue street railway certificates, secured by a mortgage on the railway, giving the mortgagee in case of foreclosure the right to maintain and operate the road for a period of not over twenty years. An ordinance providing for such certificates must, however, be submitted to popular vote and be approved by a majority of those voting on the question. It is expected that such cerificates will not be considered by the courts as part of the city debt limited by the state Constitution. When a city has secured a street railway it may operate it under direct municipal management only if that policy is approved at a popular referendum by three-fifths of those voting. Or the city may lease the road for a period not over twenty years, but any ordinance authorizing a lease for more than five years must be submitted to a referendum vote on the petition of ro per cent. of the voters. ${ }^{18}$

\section{Franchises.}

Since 1900 a number of states have established general conditions for franchises dealing with municipal services, and authorized municipal regulation of private companies operating such services. A California law of Igor provides that sales of franchises must be advertised, and that the city must receive at least 2 per cent. of the gross receipts after five years. A South Carolina statute of 1902 authorizes the grant of franchises for light and water supply, for a term of not over thirty years, on a two-thirds vote of the city council, confirmed by a majority vote of the electors. The new Ohio code provides that street railroad franchises may be granted, for not

\footnotetext{
18 For an account of the dramatic incidents connected with the passage of this bill through the Illinois House of Representatives, see the Atlantic Monthly for January, 1904.
} 
more than twenty-five years, only after three weeks' notice, to those who offer the lowest rates of fare and have secured the consent of property owners representing the greater part of the route.

In the new Virginia constitution it is provided that franchises for the use of the public streets shall not be granted without the consent of the municipal authorities, nor for a term of more than thirty years; and that they may contain provisions for public purchase at the expiration of the term. These constitutional requirements have been supplemented by an act of 1903 regulating the granting of franchises, which was afterward incorporated with some additions in the new general municipal act. It is now provided that the streets and public property of cities and towns shall not be alienated except by a vote of three-fourths of the council, and streets may not be used for street railways, water systems, gas pipes, telephones and similar purposes, except with the consent of the municipal authorities. Franchises must be limited to not more than thirty years; and elaborate provisions are established to insure publicity and competitive bidding. Advertisements inviting bids must be published for four weeks; bids must be opened and read in public session of the councii; if the highest bid is not accepted the franchise ordinance must state the reasons for preferring a lower bid, and no amendments may be made in the terms of the grant without public advertisement for ten days. The courts are given authority to enforce by mandamus the terms of the grant. Such a franchise grant may provide that at its expiration the plant as well as the property in the streets may revert to the city either without compensation or on a fair valuation of the property, but without including any value for the franchise. The city may then sell or lease the property, or, if authorized by law, may maintain and operate it.

The Kansas act of 1903 for cities over 15,000 population limits the term of franchises to not more than thirty years, but contains none of the provisions for publicity such as are contained in the Virginia act. It does, however, authorize the councils of such cities to prescribe reasonable rates for water, electricity, gas, telephones or other commodity furnished by virtue of a franchise, the question of the reasonableness of the rate fixed being subject to review by the district judges. Water works may be purchased by a city ten years after a grant has been made, but in the case of gas or electric works or street railways the city may acquire only on the termination of a 
future grant, and when it secures possession can only lease the plant or make a contract for operation. Provisions are made for appraising the value of the plant in case of purchase. By another act cities of less than 15,000 population may grant franchises for only twenty years, and the mayor and council may make contracts and fix rates to private consumers.

Some other acts passed during the legislative sessions of 1903 may also be briefly noted. A Minnesota act authorizes city councils to contract for water supply for a term not over thirty years, and for lighting for a term not over fifteen years, if there is no municipal plant. No further conditions are imposed. Wisconsin and Montana have provided for a referendum on franchises, in the first-named state on the petition of twenty per cent. of the voters, in the second named, the approval of the resident freeholders is an essential requirement. In Arkansas the councils of cities have been given power to fix reasonable rates for water, gas and electricity, on complaint and after an examination. In Missouri, cities under 30,000 population have been given the same authority with the further addition of telephone rates, and the same class of cities have been given power to grant thirty-year franchises to heating companies.

With such restrictions in franchises and municipal regulation of rates, it is clear that, even if municipal operation of such services does not become common, a larger degree of public control over the private companies is at least being established. There is perhaps some need for distinguishing between the relative importance of different conditions. Those requiring previous public notice and local consent are clearly to be commended at all times. The limitation of franchise terms to between twenty or thirty years is an essential condition if other means of control are lacking. But if a city reserves the right to revise the payments to the city at short intervals, to regulate rates of service, and to purchase the plant for the value of the tangible property, there is no need for limiting closely the duration of the franchise, and for certain works involving vast amounts of fixed capital a longer period than thirty years may be necessary. 